\title{
Moral judgment of adolescents in relation to emotional intelligence
}

\author{
PRIYA KUMARI AND PUSHPA B. KHADI
}

Received: 01.05.2015; Revised: 23.05.2015; Accepted: 29.05.2015

See end of the paper for authors' affiliations PRIYA KUMARI

Department of Human Development and Family Studies, College of Rural Home Science, University of Agricultural Sciences, DHARWAD (KARNATAKA) INDIA Email : priyakumari044@gmail.com
ABSTRACT : Moral judgment of adolescents and its relation to emotional intelligence was studied on a sample of 72 adolescents of 13 to 16 years studying in $8^{\text {th }}$ to $10^{\text {th }}$ standards of Government and private schools from urban area and government schools from rural area of Dharwad taluk of Karnataka. Moral judgment was measured with Gupta (2010) moral judgment test (MJT) and Bar-On and Parker's (2000), Emotional quotient inventory- youth version (Bar-On EQ-i: YV) was used to assess the emotional intelligence. Chi-square was used for testing the association between levels of moral judgment and emotional intelligence as well as by age and gender. The results revealed a positive and significant association between level of moral judgment and emotional intelligence. However, age and gender was not associated with level of moral judgment and emotional intelligence.

KEY WORDS: Adolescents, Moral judgment, Emotional intelligence

- HOW TO CITE THIS PAPER : Kumari, Priya and Khadi, Pushpa.B. (2015). Moral judgment of adolescents in relation to emotional intelligence. Asian J. Home Sci., 10 (1) : 215-220. 